\section{Wojciech Pikor}

Uniwersytet Mikołaja Kopernika, Toruń

wojciech.pikor@umk.pl

ORCID: 0000-0003-2656-152X

DOI: http://dx.doi.org/10.12775/BPTh.2018.011
Biblica

et

Patristica

Thoruniensia

11 (2018) 2: 209-225

ISSN (print) 1689-5150

ISSN (online) 2450-7059

\title{
Ironia jako narzędzie narracji
}

\section{Irony as a Narrative Tool}

Streszczenie. Celem artykułu jest najpierw wskazanie warunków niezbędnych dla mówienia o ironii w narracji. Dalej zostaje podjęta próba klasyfikacji różnych rodzajów ironii. Następnie omawia się sposoby interpretacji ironii w narracji. Na końcu rozważana się funkcję ironii w narracji.

Abstract. The aim of the article is fourfold. Firstly, it aims to indicate the necessary conditions to talk about the irony in narration. Secondly, it tries to classify different types of irony. Thirdly, it discusses the right way of interpretation of the irony in narration. Fourthly, it verifies the function of the irony in biblical narrations.

Słowa kluczowe: ironia; narracja; analiza narracyjna; Księga Jonasz; satyra; sarkazm.

Keywords: irony; narration; narrative analysis; Book of Jonah; satire; sarcasm.

\footnotetext{
$\mathrm{O}$
} publikowana już po śmierci Piotra Łaguny monografia poświęcona Ironii jako postawie i jako wyrazie rozpoczyna się przywołaniem wiersza Cypriana Kamila Norwida o tytule Ironia: „Uczucie zwiedza bez ironii / Szlaki bite cudzym cierpieniem, / Lecz kto był pierwej tam, wie o niej, / Że jest - koniecznym bytu cieniem” ${ }^{1}$. Ironia - „konieczny bytu cień” - jest „przede wszystkim aktem komunikacyjnym - tak w mowie potocznej, jak w wypowiedzi retorycznej, a także - co oczywiste - w dziele literackim"2. W tych różnych obszarach komunikacji ironia przybiera różne postaci i formy, występuje z odmienną intensywnością, wysyła nie zawsze wyraźne komunikaty swojej obecności, co

1 P. Łaguna, Ironia jako postawa i jako wyraz, s. 5. Od tego samego fragmentu wiersza Norwida zaczyna Michał Głowiński swój esej Ironia jako akt komunikacyjny otwierający monografię Ironia wydaną pod jego redakcją w Gdańsku w 2002 roku.

2 M. Głowiński, Ironia jako akt komunikacyjny, s. 6. 
sprawia, że wymyka się ona nie tylko prostym definicjom, ale również percepcji potencjalnego odbiorcy, który może okazać się nie od razu zdolnym do jej rozpoznania. Dotyczy to również czytelnika narracji biblijnych, w których ironia pojawia się jako jeszcze jedna strategia narracyjna zamierzona przez autora tekstu.

W opracowaniach o charakterze metodologicznym dotyczących analizy narracyjnej tekstów biblijnych ironia nie zawsze jest traktowana jako odrębne narzędzie narracji. Tym bardziej więc potrzeba poszukania odpowiedzi na kilka pytań. Czym jest ironia? Jak ją rozpoznać? Jakie rodzaje ironii można znaleźć w tekstach biblijnych? Gdzie sytuuje się ironia: w intencjach autora narracji, w tekście czy też w rozumieniu jej przez czytelnika? Co jest konieczne do właściwego odczytania ironii? Jaką wreszcie funkcję pełni ironia w narracji? Pytania te zostaną podjęte najpierw przez wskazanie elementów pozwalających na identyfikację ironii literackiej, następnie przez próbę klasyfikacji ironii w narracjach, dalej przez przybliżenie sposobów interpretacji ironii literackiej i wreszcie przez określenie roli ironii w narracji.

\section{Warunki zaistnienia ironii w narracji}

Edwin M. Good wyraża przekonanie, że „ironia, jak miłość, jest łatwiejsza do rozpoznania niż do zdefiniowania"3. Jakby na przekór tej opinii, klasyczne definicje ironii proponowane przez starożytnych retorów rzymskich wydają się być klarowne. Cyceron ( $\uparrow 43$ przed Chr.) w dziele De oratore stwierdza, iż „wyrafinowana jest ironia, kiedy mówi się rzeczy inne od tych, które się myśli"4. Kwintylian († 96 po Chr.) w Insitutio oratoria stwierdza, iż ironia to „rozumieć przeciwne od tego, co zostało powiedziane" 5 .

Co z tych klasycznych definicji wynika? Ironia jest dwupoziomowym zjawiskiem literackim, w którym dwie warstwy znaczenia stoją $\mathrm{w}$ pewnej opozycji wobec siebie. Ponieważ autor ironii (nazywany ironistą) mówi jedno, a myśli coś innego, pierwszy adresat ironii (będący w istocie ofiarą ironii) wprawdzie rozumie wypowiedź, jednak nie dostrzega rzeczywistej myśli ironisty. Obie definicje oddają prawdę o ironii, jednakże są zbyt szerokie, gdyż podobną, dwu-

3 E.M. Good, Irony in the Old Testament, s. 13.

4 „Urbana etiam dissimulatio est, cum alia dicuntur ac sentias” (De oratore, 2, 269). Cytat za: http://www.thelatinlibrary.com/cicero/oratore2.shtml\#269 (dostep: 4.06.2018).

5 „In utroque enim contrarium ei quod dicitur intellegendum est” (Institutio oratoria, 9, 2, 42). Cytat za: https://www.loebclassics.com/view/quintilian-orators_education/2002/ pb_LCL127.59.xml (dostęp: 4.06.2018). 
warstwową strukturę komunikacyjną mają też metafora i symbol. Do tego ironia jest blisko związana $\mathrm{z}$ innymi zjawiskami literackimi sobie pokrewnymi, jak chociażby satyra, sarkazm czy groteska ${ }^{6}$. $Z$ tego powodu w opracowaniach dotyczących ironii wskazuje się na różnicę między tymi różnymi środkami wyrazu a ironią, jakby wyznaczając wokół niej pewne granice. Mimo rezygnacji $\mathrm{z}$ definiowania ironii, jej teoretycy wskazują elementy formalne składające się na ironię.

Douglas C. Muecke wyróżnia cztery elementy formalne konieczne do mówienia o ironii ${ }^{7}$ :

a) kontrast między powierzchownością (appearance) a rzeczywistością (reality),

b) nieświadomość, że powierzchowność jest tylko powierzchownością (udawaną przez ironistę, realną zaś dla ofiary ironii),

c) odwrócenie rozumienia przez rozpoznanie, że powierzchowność jest tylko powierzchownością,

d) uświadomiona przyjemność wiedzy o kontraście między powierzchownością a rzeczywistością.

Zasadniczym elementem ironii jest przeciwieństwo między dwiema warstwami znaczeniowymi: poniżej jest powierzchność (pozorne znaczenie), powyżej jest znaczenie realne, której jest sprzeczne, niezgodne lub niespójne z niższym poziomem. Element sprzeczności lub niezgodności między warstwami znaczeniowymi stanowi najbardziej charakterystyczny, wyróżniający element ironii. Ofiara ironii pozostaje nieświadoma wyższego poziomu lub pozostaje na niego zamknięta. Inaczej jest z odbiorcą (czytelnikiem) ironii, który jest przez nią zaproszony do przeskoczenia na wyższy poziom, by podjąć perspektywę autora ironii. Niższy poziom ironii - poziom powierzchowności, pozoru - jest zamieszkiwany przez ofiary ironii, natomiast wyższy poziom - poziom realności - pozostaje domeną ironisty oraz - potencjalnie - poinformowanych przez niego odbiorców ironii. „Realność” w przypadku ironii jest rozumiana jako znaczenie postrzegane przez autora ironii lub jej odbiorcę ${ }^{8}$.

Ironia wymaga, by sprzeczność między powierzchnością a rzeczywistością pozostawała nieuświadomiona przez ofiarę ironii. Ta nieświadomość jest zakładana jako przejściowa, nawet jeśli ofiara ironii nie dojdzie ostatecznie do poznania realnego znaczenia. Ironia bowiem nie jest kłamstwem, w którym proponuje się tylko powierzchowność (pozorne znaczenie) przy wycofaniu realnego znaczenia. W ironii rzeczywiste znaczenie jest zakładane jako możliwe

6 Por. R.A. Culpepper, Anatomy of the Fourth Gospel, s. 166.

7 D.C. Muecke, Irony, s. 19.

8 Por. ibidem, s. 34. 
do odkrycia albo w tym, co mówi ironista, albo w kontekście, w którym to mówi. Ironia sięga zatem intencjonalnie po nieświadomość, by skłonić swojego odbiorcę do odkrycia prawdziwego znaczenia.

Ironia jako swoiste zjawisko komunikacyjne musi zostać zidentyfikowana przez odbiorcę. Rozpoznanie ironii wymaga czytelnika, który przeanalizuje oba poziomy ironii i stwierdzi, że powierzchność jest tylko powierzchownością. To skłoni go do reinterpretacji ironii, co będzie wymagało porzucenia dosłownego (powierzchownego) znaczenia na rzecz realnego znaczenia zamierzonego przez ironistę.

Pozostaje ostatecznie, zdaniem Muecke, element emocjonalny ironii - swoista zapłata emocjonalna, która przychodzi w momencie zidentyfikowania ironii przez odbiorcę ${ }^{9}$. Ten element przyjemności jest ściśle związany z fundamentalnym elementem ironii, jakim jest sprzeczność między powierzchownością i rzeczywistością. Jeśli ta sprzeczność jest oczywista, jawna, tym samym nie ma żadnego elementu do odkrycia. Jako drugi element emocjonalny Muecke wskazuje przyjemność, jaką daje wyzwolenie z bycia niewolnikiem powierzchowności, co sytuowało odbiorcę w gronie ofiar ironii. W tym kontekście Wayne C. Booth wskazuje trzeci element emocjonalny, niezidentyfikowany przez Muecke, którym jest poczucie wspólnoty tworzonej przez ironię między ironistą i odbiorcami, którzy przeszli i zamieszkali na wyższym poziomie, stając się tym samym "potencjalnymi ironistami”" ${ }^{10}$.

Powyższy opis ironii pozwala wskazać różnice zachodzące między nią a podobnymi jej zjawiskami literackim, podobnymi zarówno z punktu widzenia formalnego (figury literackie składające się z dwóch warstw znaczeniowych, np. metafora), jak i treściowego (figury literackie potencjalnie ironiczne lub pokrewne ironii, np. sarkazm, satyra).

Cechą metafory jest podobieństwo. W metaforze, która jest zestawieniem dwóch wyrażeń w celu konstrukcji nowego, indywidualnego sensu, podobieństwo zachodzi między obiektem metaforyzującym i metaforyzowanym ${ }^{11}$. Odczytanie znaczenia metafory wymaga od czytelnika uchwycenia momentu porównania dwóch rzeczy postawionych obok siebie i zdecydowania, która z cech jednego (metaforyzującego) może być zastosowana do drugiego (metaforyzowanego). $\mathrm{W}$ ironii natomiast dwie warstwy znaczeniowe łączy nie porównanie, lecz kontrast, skutkiem którego słowa znaczą coś przeciwnego, niż wydają się mówić. Odczytanie ironii wymaga od czytelnika refleksji nad przeciwieństwem

9 Por. D.C. Muecke, Irony, s. 44-46.

10 W.C. Booth, A Rhetoric of Irony, s. 37.

11 Z. Mitosek, Co z ta ironia?, s. 361. 
zachodzącym między powierzchownym (w istocie pozornym) poziomem znaczenia a realnym znaczeniem, które zamierzone jest przez autora ironii.

W przypadku zjawisk literackich pokrewnych ironii bądź potencjalnie ironicznych sprzeczność między powierzchownością a rzeczywistością jest jawna. I tak satyra jest wypowiedzią bezpośrednią, krytykującą swój obiekt wprost ${ }^{12}$. Sarkazm, w przeciwieństwie do ironii, nie jest ukryty: „podmiot sarkastycznej wypowiedzi twierdzi to, co myśli, a myśli to, co twierdzi”"13. Satyra i sarkazm są prostsze od ironii i nie wymagają złożonego procesu rekonstrukcji, jak ma to miejsce przy interpretacji ironii.

\section{Rodzaje ironii w narracji}

Trudność stanowi nie tylko podanie jednej, prostej definicji ironii, ale również dokonanie jej klasyfikacji. W pracach teoretycznych poświęconych ironii, jak i w opracowaniach dotyczących analizy narracyjnej pojawiają się pewne rozwiązania systematyzujące świat ironii literackiej. Zasadniczo wyróżnia się dwa rodzaje ironii: ironię werbalną i dramatyczną, jakkolwiek w przypadku tej ostatniej używa się też określenia „ironia sytuacyjna” ${ }^{14}$. Część jednak badaczy rozróżnia między ironią dramatyczną i sytuacyjną ${ }^{15}$. Jeśli przyjąć za kryterium rozróżnienia między typami ironii jej formę, jaka jest komunikowana przez tekst, wówczas można przyjąć klasyczne rozróżnienie między ironią werbalną (ironiczne jest słowo) oraz ironią dramatyczną (ironiczne jest to, co się dzieje).

12 Por. P. Łaguna, Ironia jako postawa i jako wyraz, s. 50.

13 Z. Mitosek, Co $z$ ta ironią?, s. 360.

14 Rozróżnienie między ironią werbalną i dramatyczną znaleźć można np. w: P. Łaguna, Ironia jako postawa i jako wyraz, s. 69-74; J.-L. Ska, „Our Fathers Have Told Us", s. 57-61; D. Marguerat, Y. Bourquin, Per leggere i racconti biblici, s. 123-124; M.H. Abrams, Glossary of Literary Terms, s. 135-138; L. Alonso Schökel, L'arte di raccontare la storia, s. 140. Podział na ironię werbalną i sytuacją proponują np.: D.C. Muecke, Ironia: podstawowe kwalifikacje, s. 46-47; K. Kłósek, Analiza narracyjna, s. 277; Z. Mitosek, Co $z$ ta ironia??, s. 355-356. Za synonimicznym traktowaniem określeń „ironia dramatyczna” i „ironii sytuacyjna” opowiadają się np. w: M.A. Powell, What is Narrative Criticism?, s. 30; D. Marguerat, Y. Bourquin, Per leggere i racconti biblici, s. 124; Z. Mitosek, Co z ta ironia?, s. 17.

15 Tak np. E. Wendland, Recursion and Variation in the 'Prophecy' of Jonah, s. 85-90. Jego zdaniem ironia dramatyczna ujawnia się przez zdarzenie, któremu towarzyszy wypowiedź o podwójnym znaczeniu, natomiast w ironii sytuacyjnej niezgodność zachodzi między zdarzeniami. 
Ironia werbalna jest najbardziej rozpowszechnioną formą ironii. Zachodzi wtedy, gdy ktoś mówi jedną rzecz, a myśli inną. Jak wynika z zestawienia różnych definicji ironii werbalnej przez Jeana Luisa Ska, większość badaczy zakłada, iż ironia werbalna jest zamierzona przez mówcę, jakkolwiek ma ona miejsce również wtedy, kiedy mówca nie jest świadomy podwójnego znaczenia swojej wypowiedzi ${ }^{16}$. W obu przypadkach ironia wynika $\mathrm{z}$ kontrastu między dwoma znaczeniami pojedynczej wypowiedzi, przy czym kontrast tkwi w samych słowach wypowiedzi, a nie w dramatycznej sytuacji (co jest właściwe ironii dramatycznej $)^{17}$. Najczęściej ironia werbalna ma miejsce, gdy jeden $\mathrm{z}$ bohaterów chce oszukać innego ${ }^{18}$. Ironia werbalna może pochodzić też od samego narratora ${ }^{19}$. Można też dopatrywać się ironii werbalnej w niektórych imionach bohaterów biblijnych ${ }^{20}$.

Ironia dramatyczna odnosi się do wydarzeń. Zakłada ona kontrast między niewłaściwym zrozumieniem jakieś sytuacji przez przynajmniej jednego z bohaterów a zrozumieniem rzeczywistej sytuacji przez czytelnika i w niektórych przypadkach również przez któregoś z bohaterów ${ }^{21}$. W tym wypadku niezgodność między tym, co powiedziane, a tym, co się myśli, jest zamierzona przez narratora. Swoją wiedzą i intencją dzieli się on z czytelnikiem, który dzięki temu rozumie głębsze znaczenie danego zdarzenia, ale nie $\mathrm{z}$ ofiarą ironii będącej wewnątrz narracji, która nie rozumie lub pozostaje nieświadoma rzeczywistego stanu rzeczy. Ironia dramatyczna polega zatem na rozdźwięku między wiedzą czytelnika(-ów) a niewiedzą bohatera(-ów) narracji.

16 J.-L. Ska, „Our Fathers Have Told Us”, s. 57.

17 Ska podaje jako przykład nadanie imienia Mojżeszowi przez córkę faraona w Wj 2,10: „wyciągnęłam go z wody”. W rzeczywistości to imię powinno brzmieć māšûy („wyciągnięty”, part. pass.), a nie mōšeh („wyciągający”, part. act.). Nieświadomy błąd córki faraona zapowiada przyszłe „wyciągnięcie” Izraela przez Mojżesza z Egiptu i z wód Morza Czerwonego („Our Fathers Have Told Us”, s. 59).

18 Przykładem mogą być słowa Labana do Jakuba, któremu obiecuje dać córkę (Rdz 29,19), tyle że ma na myśli nie tę, o której mówi wcześniej Jakub.

19 Abraham ma złożyć w ofierze na górze Moria swojego syna, jednakże to tej ofiary ostatecznie nie dochodzi. Narrator jednak kończy opowiadanie stwierdzeniem, że Abraham „Wrócił do swoich sług” (Rdz 22,19), pomijając przy tym informację o Izaaku. W ten sposób narrator świadomie podkreśla, iż ofiara ta dokonała się, jednakże na zupełnie innym poziomie niż dosłownym (materialnym) - na poziomie duchowym.

20 Por. J.-L. Ska, „Our Fathers Have Told Us”, s. 60. Przykładem może być imię Nabala (nābāal) w 1 Sm 25,3, gdzie jest on przedstawiony jako człowiek „okrutny i występny” ( $q a \bar{a} s \mathrm{e}^{h}$ wəra ). Tymczasem jest on tak naprawdę "głupcem”, na co wskazuje jego imię.

21 J.-L. Ska, „Our Fathers Have Told Us”, s. 60. 
Za podrodzaje ironii dramatycznej Ska wskazuje ironię tragiczną i ironię strukturalną ${ }^{22}$. Ironia tragiczna określa działania bohatera, którego czyny wbrew jego woli i wiedzy prowadzą nieuchronnie do katastrofy. Edwin M. Good jako przykład ironii tragicznej podaje historię Saula, który sam prowokuje swój upadek ${ }^{23}$.

O ironii strukturalnej można mówić w narracji wtedy, gdy autor, zamiast posługiwać się okazjonalnie ironią werbalną, wprowadza ją do opowiadania jako element strukturalny, który utrzymuje w nim permanentny kontrast między dwoma znaczeniami lub ocenami ${ }^{24}$. Dla osiągnięcia tego efektu narrator sięga często po „naiwnego bohatera”, który nie jest zdolny do właściwego zrozumienia i działania. Jako przykład ironii strukturalnej może posłużyć Księga Jonasza, w której prorok do końca pozostaje niezdolny do zmiany swego myślenia i działania wobec Bożego pragnienia miłosierdzia dla Niniwitów ${ }^{25}$.

Prezentując różne rodzaje ironii literackiej, należy odnieść się do jeszcze jednego schematu porządkującego typy ironii, który proponuje Kinga Kłósek w swoim opracowaniu metodologii analizy narracyjnej ${ }^{26}$. Za kryterium podziału podaje ona „stopień obecności ironii w narracji”, na podstawie którego wyróżnia:

a) ironię zamierzoną (intended irony) - „odnosi się do stwierdzenia, co do którego autor zdaje sobie sprawę, że jest nieprawdziwe [...]",

b) ironię ukrytą (covert irony) - „czytelnik sam musi ją odnaleźć. Autor domyślny i narrator milczą na temat ironicznej natury jakiegoś fragmentu narracji czy wypowiedzi [...]",

c) ironię trwałą (stable irony) - „,w tym przypadku pojawia się pewna granica, która świadczy o tym, jak głęboko zostało zmienione znaczenie. Ten rodzaj ironii jest ograniczony zakresem wyrażenia, które tylko częściowo można traktować jako ironiczne".

Przy ostatnim typie ironii (stałej) autorka odsyła do dwóch prac - Trempera Longmana Literary Approaches to Biblical Interpretation (Grand Rapids, MI 1987, 98) oraz Seymur Chatman Story and Discourse (Ithaca - London 1980, 229) - jako źródła, z którego czerpie powyższy podział. Mimo atrakcyjności proponowanego przez Kłósek schematu, należy stwierdzić, iż pozbawiony jest on logiki. W pracach, na które się powołuje, autorzy przywołują zapro-

\footnotetext{
22 Por. J.-L. Ska, „Our Fathers Have Told Us”, s. 61.

Por. E.M. Good, Irony in the Old Testament, s. 56-80.

M.H. Abrams, Glossary of Literary Terms, s. 135.

Por. J.-L. Ska, „Our Fathers Have Told Us”, s. 61.

26

K. Kłósek, Analiza narracyjna, s. 278.
} 
ponowany przez Wayne’a Bootha koncept „ironii trwałej” (stable irony). Cechy ironii trwałej są następujące ${ }^{27}$ :

a) jest zamierzona (intended) przez autora,

b) jest ukryta (covert),

c) jest trwała lub ustalona (stable or fixed) w tym sensie, że „raz dokonawszy rekonstrukcji znaczenia, czytelnik nie jest zapraszany do podważania jej przez dalsze niszczenie i rekonstrukcje",

d) jest ograniczona (finite) w tym sensie, że nie jest nieskończona - tylko część tekstu może być ironiczna.

Odnieść można wrażenie, że Kłósek cechy „ironii stałej” wskazane przez Bootha, a powtórzone przez Chatman i Longmana, potraktowała jako odrębne typy ironii, przy czym dwie ostatnie cechy połączyła w jedną. Autorka nie zauważa, że warunkiem spójności logicznej podziału jest koherencja między poszczególnymi elementami, które razem winny tworzyć zamknięty zbiór logiczny. Tymczasem dopełnieniem ironii „zamierzonej” będzie ironia „niezamierzona”, ironii „ukrytej” - „jawna” itd. Takie podejście do typów ironii prezentuje Booth, który rozróżnia między ironią stałą (stable) i niestałą (unstable), by następnie przemieszczając wyszczególnione przez siebie antynomiczne cechy ironii (overt - covert, finite - infinite), wyróżniać jeszcze inne podgrupy wewnątrz ironii stałej i niestałej. Dla porządku dodać należy, jak Booth rozumie ironię niestałą (unstable irony): zachodzi ona wtedy, gdy „autor - na ile jesteśmy w stanie go odkryć, a jest on często rzeczywiście bardzo odległy odmawia, jakkolwiek subtelnie, opowiedzenia się, za jakimkolwiek trwałym twierdzeniem (any stable proposition)" 28 . Bootha rozumienie ironii doczekało się krytyki wielu badaczy, spośród których na czoło wysuwa się Stanley Fish. Zawrócił on uwagę, iż wskazane przez Bootha cechy ironii stałej nie mogą być traktowane jako „sygnały obecności ironii, gdyż właśnie ich obecność jest przedmiotem dyskusji, czy dane dzieło jest ironiczne"29. W konsekwencji Fish zakwestionował logikę podziału na ironię „stałą” i „niestałą”, podkreślając, iż „ironia zawsze pozostanie niestała, jeśli będzie poddawana interpretacji” ${ }^{30}$.

27 W.C. Booth, A Rhetoric of Irony, s. 5-6.

28 Ibidem, s. 240.

29 S. Fish, Short People Got No Reason to Live, s. 176.

30 Ibidem, s. 190. 


\section{Sztuka interpretacji ironii}

Dyskusja nad różnymi rodzajami ironii doprowadziła do pytania o sposób interpretacji tego zjawiska literackiego. Ironia ma, jak zostało to wykazane, określoną konstrukcję, która zamierzona przez swego autora jest wyrażana za pomocą tekstu. Bez wątpienia ironia jest pewną sztuką literacką, która wymaga określonych umiejętności od autora. Sięga on w ironii po słowa mające konkretne znaczenie, jednakże w jego intencji ich wymowa jest sprzeczna $\mathrm{z}$ ich dosłownym znaczeniem. $\mathrm{W}$ momencie spisania ironii intencje jej autora są dostępne wyłącznie $\mathrm{w}$ tekście, przez który komunikuje się on $\mathrm{z}$ odbiorcą. Jeśli komunikacja ironii ma być efektywna, wymaga ona czytelnika. Ironia jest wewnątrz tekstu, ale w akcie czytania staje się czymś wewnątrz reakcji czytelnika. To od czytelnika zależy decyzja o wnioskowaniu o ironii w tekście lub przypisaniu jej tekstowi ${ }^{31}$. By jego interpretacja mogła pójść $\mathrm{w}$ tym kierunku, potrzebuje on pewnych sygnałów ironicznych. Można założyć, że inteligentni czytelnicy identyfikują ironię intuicyjnie, nawet gdy nie są w stanie dokładnie wyjaśnić podstaw swojej intuicji. Autor ironii, zainteresowany jej odczytaniem przez odbiorców, pozostawia w tekście pewne sygnały ironiczne. Ironia utrwalona na piśmie rezygnuje ze znaków ironii typowych dla języka mówionego, którymi są np. mrugnięcie oczami, wydęcie warg czy ton głosu ${ }^{32}$. Oczywiście, są dostępne w tekście pewne znaki interpunkcyjne, które mogą między innymi oznaczać ironię: pauzy, wielokropki lub wykrzykniki w nawiasach. Nie one jednak stanowią o ironii literackiej. Ta bowiem jest „tym bardziej ironiczna, im bardziej zdecydowanie potrafi zrezygnować z ironicznych sygnałów, nie tracąc swej przejrzystości”33.

Gdzie zatem czytelnik może szukać w tekście sygnałów ironicznych? Teoretycy ironii są w swoich odpowiedziach zgodni: klucz do ironii zawiera w kontekście ${ }^{34}$. Kontekst umożliwia nie tylko rozpoznanie wszelkich napięć wewnątrz ironii, ale również zrozumienie, co jest w niej prawdziwe, a co fałszywe. „Trzeba jednak pamiętać - jak zauważa Booth - że nie możemy z wyprzedzeniem poznać, która $\mathrm{z}$ wielu możliwych kontekstualnych kwestii będzie

31 Por. C.J. Sharp, Irony and Meaning in the Hebrew Bible, s. 25.

32 Por. B. Allemann, O ironii jako kategorii literackiej, s. 26.

33 Por. ibidem. Muecke mówi w tym kontekście o zasadzie ekonomii, zgodnie z którą dobry ironista użyje jak najmniej sygnałów ironii, jak to jest możliwe (Irony, 52).

34 Por. W.C. Booth, A Rhetoric of Irony, s. 91; P. Łaguna, Ironia jako postawa i jako wyraz, s. 71; B. Allemann, O ironii jako kategorii literackiej, s. 27; C.J. Sharp, Irony and Meaning in the Hebrew Bible, s. 22-24. 
znacząca [dla uchwycenia ironii] - inne części pracy, wiedza na temat życia i czasów autora czy też najgłębsze przekonania autora na temat tego, co prawdopodobnie powie na poważnie" 35 . Kontekst, wewnątrz którego tekst ironiczny jest skonstruowany, może być zatem różnorodny. Muecke wskazuje tu na formę literacką i lingwistyczną, znajomość uwarunkowań politycznych i społecznych oraz możliwość ich wpływu na powstanie tekstu, obeznanie ze starożytnymi gatunkami i tradycjami, wyczucie artystycznego stylu, temperament teologiczny i retoryczny wydźwięk tekstu ${ }^{36}$. Który z tych kontekstów jest istotny dla zrozumienia ironii, jest wynikiem wyborów dokonanych przez autora oraz wyciągniętych przez czytelnika wniosków o tych wyborach. W rezultacie „ocena poprawności, znaczenia i sensu ironii będzie się różniła między czytelnikami w zależności od różnego rozumienia tekstu, politycznego i ideologicznego kontekstu, konstrukcji domyślnego odbiorcy i innych zmiennych wpływających na proces czytania" ${ }^{37}$. Jedną z tych innych zmiennych wydaje się np. fakt udzielenia czytelnikowi przez autora ironii pewnych informacji, które są nieznane ofierze ironii.

Część badaczy zajmujących się analizą narracyjną Biblii opowiada się za interpretacją ironii na bazie procedury jej rekonstrukcji zaproponowanej przez Bootha ${ }^{38}$. Wyróżnia on cztery etapy odkrywania ironii:

a) czytelnik odrzuca dosłowne znaczenie słów, gdyż rozpoznaje pewne niezgodności między słowami. Równocześnie uświadamia sobie, że „jeśliby autor nie zamierzał ironii, byłoby to dziwne, albo cudaczne, albo nieporadne, albo głupie w uczynieniu takich rzeczy"39;

b) czytelnik próbuje alternatywnej interpretacji lub wyjaśnienia ironii, które będą niezgodne, a nawet sprzeczne, $\mathrm{z}$ dosłownym rozumieniem odrzuconych słów;

c) czytelnik ocenia te interpretacje w świetle tego, co jego zdaniem autor (domyślny) ironii myśli i w co wierzy;

35 W.C. Booth, A Rhetoric of Irony, s. 91.

36 D.C. Muecke, Irony Markers, s. 367.

37 C.J. Sharp, Irony and Meaning in the Hebrew Bible, s. 25. W pewnym stopniu o właściwym odczytaniu kontekstu przez odbiorcę decyduje sam autor ironii, który komunikuje się wprawdzie z „realnym czytelnikiem”, ale zakłada też „domyślnego czytelnika”, z którym dzieli wspólne doświadczenie językowe, kulturowe, aksjologiczne itd. (por. W.C. Booth, A Rhetoric of Irony, s. 100).

38 Czterostopniową procedurę dekonstrukcji, a następnie rekonstrukcji ironii proponuje Booth w A Rhetoric of Irony, s. 10-13. Ten schemat badawczy jest przytaczany m.in. w: R.A. Culpepper, Anatomy of the Fourth Gospel, s. 167; D. Marguerat, Y. Bourquin, Per leggere i racconti biblici, s. 123; K. Kłósek, Analiza narracyjna, s. 278.

39 W.C. Booth, A Rhetoric of Irony, s. 52-53. 
d) dokonawszy decyzji co do wiedzy i przekonań autor, czytelnik wybiera nowe znaczenie słów, które mógł mieć na myśli autor ironii.

Procedura interpretacji ironii proponowana przez Bootha zakłada, iż ironia zasadza się na opozycji między tym, co jest, a tym, co nie jest powiedziane. Odmienne spojrzenie od Bootha na interpretację ironii wysunęła Linda Hutcheon, która zwróciła uwagę na dynamikę interakcji między powiedzianym a niepowiedzianym jako kluczową dla zrozumienia ironii ${ }^{40}$. Jak zostało to już zasygnalizowane, ironia funkcjonuje do pewnego stopnia analogicznie jak metafora: zarówno metafora jak i ironia mają dwa poziomy znaczeniowe, tyle że znaczenie metafory jest odczytywane przez podobieństwo między dwiema warstwami znaczeniowymi, zaś odczytanie znaczenia ironii wymaga uchwycenia różnicy między dwoma poziomami. Dialektyczna relacja między powiedzianym a niepowiedzianym tworzy „trzecie” znaczenie - znaczenie ironiczne, które nie jest prostym przeciwieństwem powierzchowności - znaczenia dosłownego, a tym samym pozornego ironii.

W interpretacji wypowiedzi ironicznej nie chodziłoby zatem o wykluczenie jej dosłownego znaczenia na rzecz jej znaczenia właściwego, zamierzonego przez autora. Powiedziane i niepowiedziane są obecne razem i znaczą razem, tworząc wielowymiarowy akt komunikacyjny ironii. Z tego powodu Muecke uważa, że „ironia jest czymś do delektowania się, a nie do zwykłego rozwiązania. Delektuje się umiejętność, z jaką oba znaczenia pozorne i rzeczywiste są stworzone do koegzystowania. Pozorne znaczenie jest przekonywująco utrzymywane przez udawanie, natomiast przeciwne, rzeczywiste znaczenia jest stale aluzyjnie przywoływane" ${ }^{41}$. Ironia literacka znaczy „więcej niż”: więcej niż jest powiedziane, więcej niż oczekuje czytelnik i więcej niż może być sądzone $\mathrm{z}$ identyfikowanego przeciwieństwa między poziomami ironii ${ }^{42}$.

Jeśli zatem opozycja między przekazem pozornym (dosłownym) a zamierzonym (rzeczywistym) nie sprowadza się do prostej relacji przeciwieństwa, wówczas odczytanie ironii wymaga, zdaniem Carolyne Sharp - zrozumienia przez czytelnika relacji między trzema elementami ${ }^{43}$ :

a) co jest powiedziane,

b) co jest milcząco stwierdzone przez odrzucenie tego, co powiedziane,

c) co jest uczynione widzialnym za pomocą interakcji między powiedzianym i niepowiedzianym.

40 L. Hutcheon, Irony's Edge, s. 59-66. Podąża za nią C.J. Sharp, Irony and Meaning in the Hebrew Bible, s. 202-21, 23.

41 D.C. Muecke, Irony Markers, s. 366.

42 Por. C.J. Sharp, Irony and Meaning in the Hebrew Bible, s. 21.

43 Ibidem, s. 23. 
Ten trzeci element stanowi klucz do interpretacji ironii, która jest swoistą interakcją między negacją tego, co powiedziane, a afirmacją tego, co nie jest powiedziane. Nowe znacznie ironii uchwycone przez czytelnika opiera się na tym, co powiedziane, a zarazem to, co powiedziane, przekracza.

Proponowane przez Hutcheon spojrzenie relacyjne, a nie binarne na ironię pozwala uniknąć pokusy sprowadzania interpretacji ironii do prostej, mechanicznej procedury. Interpretacja metafory jest raczej sztuką niż nauką, bardziej umiejętnością i rzemiosłem zdobywanym i doskonalonym przez powtarzane doświadczenie i naśladowanie innych niż mechaniczne techniki.

\section{Funkcja ironii w narracji}

Ironia literacka jest zapośredniczona przez tekst narracji. Jednakże, jak zostało to wspomniane wcześniej, ironia sytuuje się nie tylko w tekście, ale również $\mathrm{w}$ intencjach narratora i w interpretacji czytelnika. Funkcja narracyjna ironii może być zatem być rozpatrywana w jej relacji do tych trzech podmiotów tworzących akt komunikacyjny, jak i w relacji, jakie tworzą te podmioty między sobą.

Narrator komunikuje się z czytelnikiem za pośrednictwem tekstu. Tekst jest medium, w którym czytelnik spotyka autora domyślnego narracji. Ironia w tym wypadku, jako figura zamierzona przez autora, odsłania punkt widzenia jej autora, jego świat wartości, jego sposób postrzegania świata. Czytelnik jest zaproszony do współtworzenia historii opowiedzianej w tekście, co wymaga od niego nie tylko odczytania fabuły, ale również re-kreacji bohaterów. W obu przypadkach ironia wpisuje się $\mathrm{w}$ pewną strategię narracyjna przyjętą przez narratora, który pragnie, by czytelnik z pozycji zewnętrznej wobec narracji wszedł w jej przestrzeń, współtworząc ją niejako od środka. Jednakże bez czytelnika, który odkryje ironię i ją zinterpretuje, ironia będzie pozbawiona swego znaczenia komunikacyjnego. Dlatego też funkcję ironii w narracji - dramatyzująca, komiczna, dydaktyczna i wspólnototwórcza - będzie rozpatrywana perspektywie jej relacji wobec czytelnika.

\subsection{Funkcja dramatyzująca}

Narracja układa się według określonego modelu, w ramach którego można wyróżnić ekspozycję, rozwinięcie, komplikację, punkt kulminacyjny, perypetię, suspens i rozwiązanie ${ }^{44}$. Model ten może być wykorzystany za każdym razem

44 Por. J.-L. Ska, „Our Fathers Have Told Us”, s. 19-30. 
inaczej, jednak jego istotne cechy pozostają bez zmian. Akcja ma charakter dynamiczny, ale nie musi rozwijać się harmonijnie ani też linearnie. Temu służą pewne elementy przywołanego „szkieletu fabuły”, przede wszystkim komplikacja i suspens, których celem jest udramatyzowanie akcji. Dla zbudowania nie tylko komplikacji czy suspensu narrator może sięgnąć po ironię. W swej dwuwarstwowej strukturze znaczeniowej niesie ona pewną sprzeczność, niezgodność, która burzy harmonijny rozwój akcji. Ironia dramatyczna (sytuacyjna) może pojawić się w momencie zwrotu akcji, szczególnie zmiany sytuacji bohatera (peripeteia). Ironia może wręcz wpływać na kształt całej narracji, jeśli przywołać ironię strukturalną nadającą całej narracji odcień ironiczny - to jest przypadek Księgi Jonasza.

Ofiary ironii niekoniecznie uświadomią sobie wpisaną w nią niezgodność, ale czytelnik ma możliwość uchwycenia jej, a tym samym dostrzeżenia, jak wpływa ona na sytuację bohaterów, rozwój zdarzeń czy realizację programu narracyjnego. Dzięki wykorzystaniu ironii w narracji, postaci, które stają się jej ofiarami, przestają być bohaterami „płaskimi” (flat characters) - pozbawionymi cech indywidualizujących, statycznymi, niczym niezaskakującymi w trakcie opowiadania, a ujawniają swoją „złożoność” (round characters) wyrażającą się w złożoności myślenia i działania, osobowości i charakteru.

Ironia, mimo że jawi się elementem zakłócającym fabułę, stanowi niezbędne narzędzie narracji. Dzięki ironii opowiadanie staje się bardziej dramatyczne, nieprzewidywalne i zaskakujące, zaś bohaterowie - ofiary ironii - zyskują na indywidualności i wyrazistości.

\subsection{Funkcja komiczna ${ }^{45}$}

Nie każda ironia jest zabawna i wzbudza wesołość czytelnika. Wystarczy przywołać ironię tragiczną, która może co najwyżej wzbudzić „śmiech przez łzy”. Jednakże ironia stanowi „wyjątkowo subtelny przejaw komizmu”46, co bez wątpienia sprawia, iż w pewnych okolicznościach może ona pełnić funkcję komiczną $\mathrm{w}$ narracji. Ironia nie do końca jest tożsama $\mathrm{z}$ humorem, który jest wypowiedzią bezpośrednio aprobującą dany podmiot. W przypadku ironii dochodzi do pewnej negacji podmiotu, który jest jej ofiarą, co nie przekreśla możliwości zaistnienia komizmu sytuacyjnego, który wzbudzi w czytelniku silne

45 Davis S. Kaufer mówi o funkcji satyrycznej ironii (Ironia, forma interpretacyjna i teoria znaczenia, s. 317), jakkolwiek należy pamiętać, że istotą satyry jest skrytykowanie podmiotu przez ośmieszenie go wprost. Wyrażenie „funkcja komiczna” zwraca uwagę na ironię jako czynnik wyzwalający radość i zadowolenie u czytelnika, który ją rozpoznaje.

46 P. Łaguna, Ironia jako postawa i jako wyraz, s. 50. 
emocje pozytywne. Czynnikiem wyzwalającym taką reakcję jest na pierwszym miejscu zaskoczenie, które staje się udziałem czytelnika wobec uświadomienia sobie w danej ironii pewnej niedorzeczności czy wręcz absurdalności, które pozostają poza świadomością ofiary ironii ${ }^{47}$.

Funkcja komiczna ironii nie stoi w sprzeczności z innymi jej funkcjami, o czym można się przekonać czytając Księgę Jonasza. Obecna w niej ironii strukturalna kilkakrotnie budzi reakcję zdziwienia czytelnika właśnie z powodu swej komiczności. Obecna np. w Jon 1,5 ironia sytuacyjna, mimo tragizmu zdarzenia, jakim jest burza na morzu, jest komiczna: podczas gdy marynarze walczą o uratowanie statku, również zwracając się w modlitwie do swoich bóstw, Jonasz „schodzi w głąb wnętrza okrętu, kładzie się i głęboko zasypia”48. Czytelnik uśmiecha się, próbując wyobrazić sobie śpiącego Jonasza na okręcie miotanym falami, które za chwilę mają go zatopić.

\subsection{Funkcja dydaktyczna}

Ironia rodzi się z niezgodności między „jest” a „powinno być”, dlatego - jak zauważa Good - „ironia domaga się moralnego porządku”49. W konsekwen-

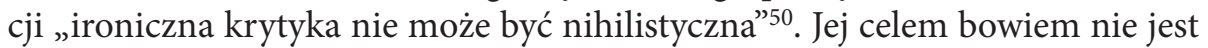
zniszczenie niezgodności, lecz jej naprawienie.

Sięgając po ironię, narrator odwołuje się do systemu wartości, który wyznaje. Ironia służy mu do wyrażenia swojej oceny myślenia i działania ofiar ironii. W istocie dystansuje się wobec określonych działań i postaw bohaterów narracji, które ocenia negatywnie. Jego uwaga nie skupia się jednak na samej narracji i jej bohaterach, gdyż opowiadanie jest tylko środkiem dotarcia do czytelnika (odbiorcy), który dostrzegając ironię, podejmie się jej interpretacji. Odczytanie rzeczywistego znaczenia ironii, a nie pozornego, będącego udziałem ofiar ironii, ma doprowadzić czytelnika do przyjęcia punktu widzenia narratora, jego ocen, systemu wartości i wizji świata ${ }^{51}$.

47 Por. A. Strug, Od śmiechu do ironii, s. 40.

48 Inne przykłady funkcji komicznej ironii w Księdze Jonasza podaje: E. Wendland, Recursion and Variation in the 'Prophecy' of Jonah, s. 90-92.

49 E.M. Good, Irony in the Old Testament, s. 25.

50 Ibidem, s. 31.

51 D. Marguerat, Y. Bourquin, Per leggere i racconti biblici, s. 124. D.S. Kaufer mówi w tym kontekście o „przyjęciu perspektywy” autora ironii, za którą kryją się „określone działania i postawy, takie jak refleksja, kojarzenie, rozdzielanie itp." (Ironia, forma interpretacyjna i teoria znaczenia, s. 324). 
Funkcja dydaktyczna ironii dotyczy szczególnie ironii dramatycznej, co zauważa się przykładowo w Księdze Jonasza. Wyznanie wiary w miłosierdzie Boże, które wypowiada Jonasz, widząc ocalenie Niniwy, jest ironiczne, gdyż przekonanie właśnie o miłosierdziu Boga skłoniło go (i nadal skłania) do odrzucenia misji wobec Niniwitów: „dlatego postanowiłem uciec do Tarszisz” (Jon 4,2). Czytelnik ma nie tylko odkryć sprzeczność między słowami Jonasza a jego postawą - sprzeczność, której on sobie nie uświadamia - ale również ma przyjąć odwrotną od proroka postawę wobec Niniwitów, jako że Bóg pragnie okazać swoje miłosierdzie wszystkim, także poganom.

\subsection{Funkcja wspólnototwórcza}

Funkcję budowania wspólnoty przez ironię Mark A. Powell rozumie następująco: „Ironia ustanawia rodzaj wspólnoty między domyślnym autorem i domyślnym czytelnikiem, przez którą ten drugi jest prowadzony do szczególnego zrozumienia narracji” ${ }^{52}$. Wspólnota między narratorem i czytelnikiem zawiązuje się wtedy, gdy ten ostatni przyjmuje $\mathrm{w}$ akcie interpretacji punkt widzenia tego pierwszego, co oznacza zaakceptowanie jego systemu wartości i bazującego na nim działania. W konsekwencji czytelnik staje się, używając określenia Bootha, "potencjalnym ironistą" 53 .

Bibliści korzystający $\mathrm{z}$ analizy narracyjnej w interpretacji Ewangelii Markowej i Janowej wspólnototwórczą rolę ironii widzą nieco szerzej: nie chodzi bowiem tylko o wspólnotę między narratorem i czytelnikiem, ale również o wspólnotę wewnątrz "grupy czytelników” 54 . Ironia pomaga grupie czytelników, np. Ewangelii Janowej, na zdefiniowane swojej tożsamości przez stworzenie dystansu między tymi, którzy są w stanie uchwycić ironię i ją odczytać, a tymi, którzy jej nie zauważają, a tym samym nie interpretują. Dzięki temu, że ironia odczytywana dosłownie oferuje pozorne znaczenie, grupa otrzymuje możliwość budowania swojej wspólnoty wiary i życia na rzeczywistym znaczeniu ironii.

Wspólnototwórcza rola ironii w szerszym znaczeniu tej funkcji jest dostrzegalna w Księdze Jonasza. Jonasz, który reprezentuje naród wybrany, w istocie odrzuca nie mieszkańców Niniwy, ale nową koncepcję ludu Bożego, która rodzi się po wygnaniu babilońskim. Stąd też właściwe odczytanie ironii obecnej wręcz strukturalnie w tej księdze ma doprowadzić czytelnika do przyłączenia

M.A. Powell, What is Narrative Criticism?, s. 28.

Por. przyp. 10.

54

D. Marguerat, Y. Bourquin, Per leggere i racconti biblici, s. 124.
} 
się do wspólnoty ludzi otwartych na Boże miłosierdzie, wspólnoty przekraczającej, a nawet znoszącej granice etniczne.

Podsumowując, należy z całym przekonaniem stwierdzić, iż ironia jest istotnym narzędziem narracyjnym wykorzystywanym przez autora tekstu. Funkcje ironii - dramatyzująca, komiczna, dydaktyczna i wspólnototwórcza - są ukierunkowane przede wszystkim na czytelnika, który interpretując ironię, ma przyjąć punkt widzenia jej autora. Proces interpretacji w tym wypadku nie sprowadza się do prostego wykluczenia dosłownego znaczenia ironii na rzecz jej znaczenia właściwego. Powiedziane i niepowiedziane w ironii muszą istnieć razem, skoro jej znaczenie jest swoistą interakcją między negacją tego, co powiedziane, a afirmacją tego, co nie jest powiedziane. Wobec tego napięcia dialektycznego interpretacja ironii pozostaje bardziej sztuką niż rzemiosłem.

\section{Bibliografia}

Abrams M.H., Glossary of Literary Terms, Boston, MA ${ }^{7} 1999$.

Allemann B., O ironii jako kategorii literackiej, w: Ironia, red. M. Głowiński, Gdańsk 2002, s. 17-41.

Alonso Schökel L., Larte di raccontare la storia. Storiografia e poetica narrativa nella Bibbia (Lectio 6), Roma - Cinisello Balsamo (Milano) 2013.

Booth W.C., A Rhetoric of Irony, Chicago - London 1974.

Fish S., Short People Got No Reason to Live. Reading Irony, Daedalus 112/1 (1983), s. $175-191$.

Głowiński M., Ironia jako akt komunikacyjny, w: Ironia, red. M. Głowiński, Gdańsk 2002, s. 5-16.

Good E.M., Irony in the Old Testament, Sheffield ${ }^{2} 1981$.

Kaufer D.S., Ironia, forma interpretacyjna i teoria znaczenia, Pamiętnik Literacki 77/1 (1986), s. 315-326.

Łaguna P., Ironia jako postawa i jako wyraz. Z zagadnień teoretycznych ironii, Kraków-Wrocław 1984.

Marguerat D., Bourquin Y., Per leggere i racconti biblici, Roma ${ }^{2} 2011$.

Mitosek Z., Co z ta ironia?, Gdańsk 2013.

Muecke D.C., Ironia: podstawowe kwalifikacje, w: Ironia, red. M. Głowiński, Gdańsk 2002, s. 43-74.

Muecke D.C., Irony Markers, Poetics 7 (1978), s. 363-375.

Muecke D.C., Irony. The Critical Idom, London 1970.

Powell M.A., What is Narrative Criticism? A New Approach to the Bible, Minneapolis, MN 1990. 
Sharp C.J., Irony and Meaning in the Hebrew Bible (Indiana Studies in Biblical Literature), Bloomington, IN 2009.

Ska J.-L., „Our Fathers Have Told Us”. Introduction to the Analysis of Hebrew Narratives (Subsidia Biblica 13), Roma 1990.

Strug A., Od śmiechu do ironii. Wstęp do problematyki ironizowania, Roczniki Humanistyczne 59/4 (2011), s. 29-59.

Wendland E., Recursion and Variation in the 'Prophecy' of Jonah. On the Rhetorical Impact of Stylistic Technique in Hebrew Narrative Discourse, with Special Reference to Irony and Enigma, Andrews University Seminary Studies 36/1 (1998), s. $81-110$. 